\title{
Analysis of traumatic ulcer healing time under the treatment of the Mauli banana (Musa acuminata) $25 \%$ stem extract gel
}

\author{
Dewi Puspitasari*, Maharani Laillyza Apriasari** \\ *Department of Dental Material Faculty of Dentistry Universitas Lambung Mangkurat \\ **Department of Oral Medicine Faculty of Dentistry Universitas Padjadjaran
}

\begin{abstract}
Introduction: Traumatic ulcer is one of oral disorders that often occur. The prevalence is quite high, between $3-24 \%$ of population. Therapy of traumatic ulcer is symptomatic. People usually use Aloe vera extract gel. Previous research showed that the Aloe barbadensis milleer gel is equivalent with ethanol extract of $25 \%$ Mauli banana (Musa acuminata) stem in accelerating wound healing based on the number of macrophages and neovascular. The objective of the study is to find out the time difference of traumatic ulcer healing using $25 \%$ Musa acuminata stem extract gel compared to a gel containing Aloe vera extract. Methods: The research was post test design. Subjects were patients of Oral Medicine Installation in Gusti Hasan Aman Dental Hospital Banjarmasin with diagnosis of traumatic ulcer using completely random sampling method. Eight patients as samples were determined by the formula of Lemeshow. Results: there was no significant difference with $p=0.724$ ( $p>0.05)$ between healing time using Aloe vera gel and $25 \%$ Musa acuminata stem extract. Conclusion: At the concentration of $25 \%$ Musa acuminata stem extract gel concentration has the same healing time with Aloe vera gel, therefore can be recommended as a topical use for traumatic ulcer healing.
\end{abstract}

Keywords: Musa acuminata stem, healing time, traumatic ulcer

P-ISSN 1979-0201, e-ISSN 2549-6212 Available from:http://jurnal.unpad.ac.id/pjd/index

DOI:http://dx.doi.org/10.24198/pjd.vol29no1.11598

Submission: Jan 2017 Publishing: March 2017

\section{INTRODUCTION}

Traumatic ulcer is one of oral disorder that often occur, characterized by ulcerative lesions with loss of epithelial layer exceed the basal membrane. ${ }^{1,2}$ The prevalence of traumatic ulcer quite high. Several research showed variation range $3-24 \%$ of population. ${ }^{3}$ Oral ulcer will disrupt the process of mastication, resulting in nutrient intake disorders. Therapy in oral ulceration is symptomatic intended to reduce inflammation, pain, and accelerate lesion healing. ${ }^{4,5}$

The oral ulcer potentially degenerate into secondary infections, because there are many microorganisms inside the oral cavity. Microorganisms inside the oral cavity,so the treatment with topical medicine that contained antiseptic was needed to accleerate lesion healing. So far, people use Aloe vera extract gel to treat oral ulcers. Previous laboratorium test 
showed that Aloe vera extract gel was equivalent to ethanol extract of Musa acuminata $25 \%$ in accelerating wound healing in mice by observing the number of macrophages and neovascular. ${ }^{6}$ Aloe vera extract gel is one of the topical antiseptic medicine used to cure oral ulceration in dentistry, but it is expensive and uneasy to find in some remote areas.

Clinically Musa acuminata stem extract capable to accelerate the healing of oral mucosal lesions in mice compared to Aloe vera extracts gel. ${ }^{7}$ The ethanol extract of Musa acuminata $25 \%$ capable to accelerate the healing of oral mucosal incision lesions in mice by increasing the amount of neovascular on the 5 th day and declined on the $7^{\text {th }}$ day. ${ }^{6}$ Other research showed that the methanol extract of Musa acuminata stem extract was not toxic towards the BHK (Baby Hamster Kidney) fibroblast cells 21 at the concentration of $25 \% .^{8}$ In oral administration, the methanol extract of $100 \%$ Musa acuminata stem extract between the dose of $125 \mathrm{mg} / \mathrm{kg}$ bw up to $1000 \mathrm{mg} / \mathrm{kg}$ bw, did not cause any toxic effects on the liver of mice. ${ }^{9}$

Information about the use of Musa acuminata stem still very limited. Until now, the studies about the use of Musa acuminata stem as a medicinal plant is still small. Various studies using Musa acuminata stem extract has been done both in vitro and in vivo. ${ }^{6.7}$ Based on these descriptions, it is necessary to conducted clinical research to determine the traumatic ulcer healing time difference under the treatment with Musa acuminata stem extract gel compared to the treatment with Aloe vera extract gel.

\section{METHODS}

The research was post test only design. Subjects were patients of Oral Medicine Installation in Gusti Hasan Aman Dental Hospital Banjarmasin with diagnosis of traumatic ulcer using completely random sampling method. The inclusion criteria were aged 19-35 years old, not consuming antihistamines and corticosteroids for 1 week, and not suffering any systemic disease. Eight patients as samples were determined by the formula of Lemeshow.

Tools used in this study were cotton, cotton roll, sterile cotton, ruler, tweezers, and a dental mirror No. 4. The treatment group was given a $25 \%$ Musa acuminata stem extract gel for traumatic ulcer therapy, whilst the control group was given Aloe vera extract gel. The making of Musa acuminata stem extract gel was done by using ethanol with maceration method using a vacuum rotary evaporator under the temperature of $40-50^{\circ} \mathrm{C}$. This extract then made into gel preparations with concentration of $25 \%$, applied topically on the ulcer traumatic and 3 times daily within a period of 6-8 hours each application until the traumatic ulcers healed.

\section{RESULTS}

Hypothesis test used was unpaired $t$ test parametric. Based on the Shapiro-Wilk test $(p>$ $0.05)$ and homogeneity of variance Levene's test ( $p<0.05$ ) obtained that data distribution was normal and data variance was not homogeneous.

In Table 1 shown traumatic ulcer healing time on group of Musa acuminata stem extract (MASE) application and group of Aloe vera (ALOE) application on daily basis. Traumatic ulcer healing criteria based on clinical manifestations that the lesions had recovered, had the same color with the surrounding tissue and no signs of inflammation.

Table 2 showed the average value of traumatic ulcer healing time in group of Musa acuminata stem extract (MASE) application was 6.88 days. The value longer than the group of Aloe vera (ALOE) application, which was 6.50 days.

Tabel 1. Traumatic ulcer healing time

\begin{tabular}{cccc}
\hline Patients & Time (Day) & Patients & Time (Day) \\
\hline MASE 1 & 6 & ALOE 1 & 5 \\
MASE 2 & 9 & ALOE 2 & 7 \\
MASE 3 & 4 & ALOE 3 & 4 \\
MASE 4 & 9 & ALOE 4 & 5 \\
MASE 5 & 8 & ALOE 5 & 10 \\
MASE 6 & 7 & ALOE 6 & 10 \\
MASE 7 & 7 & ALOE 7 & 6 \\
MASE 8 & 5 & ALOE 8 & 5 \\
\hline
\end{tabular}

Tabel 2. Unpaired $t$ test result of traumatic ulcer healing time

\begin{tabular}{lccc}
\hline & $\begin{array}{c}\text { Mean } \pm \text { DS } \\
\text { (day) }\end{array}$ & $\begin{array}{c}\text { Mean difference } \\
(\text { Cl 95\%) }\end{array}$ & P \\
\hline MASE & $6,88 \pm 1,8$ & $0,38(1,9-2,6)$ & 0,724 \\
ALOE & $6,50 \pm 2,3$ & & \\
\hline
\end{tabular}

Note: Unpaired t test, if $p<0.05=$ significant differences 


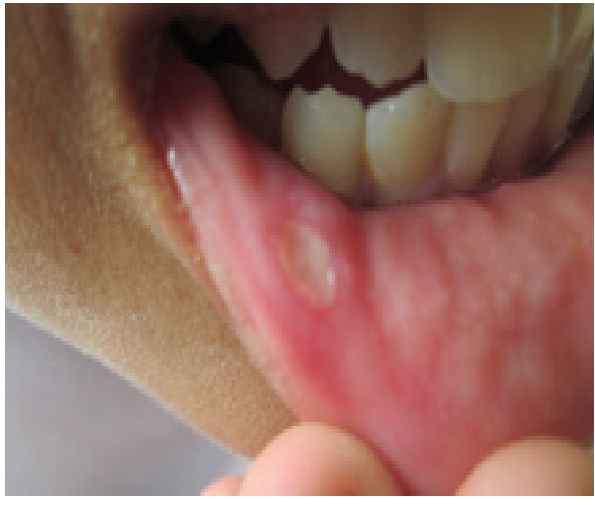

A

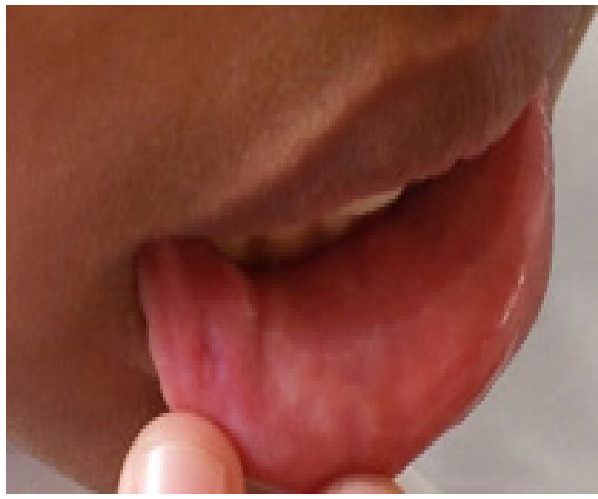

B

Figure 1. Traumatic ulcer before (A) and after (B) medical treatment (Personal Doc.)

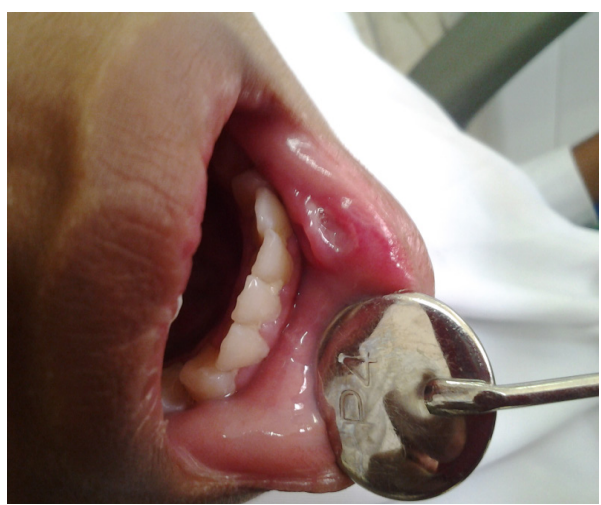

Figure 2. Lesions of traumatic ulcer (Personal doc.)

But based on significance value $(p>0.05)$, the difference between the healing time of Aloe vera gel application and $25 \%$ of Musa acuminata stem extract was not quite significant. Traumatic ulcer healing showed in Figure 1 and Figure 2.

\section{DISCUSSION}

From the results obtained that traumatic ulcer healing time under the treatment of 25\% Musa acuminata stem extract gel showed no significant differences with the treatment of Aloe vera gel. Musa acuminata stem extract contains bioactive ingredients especially tannins and saponin. ${ }^{8}$ Condensed tannins having antioxidant effect that able to reduce the Reactive Oxygen Species (ROS), as proved in previous research that Musa acuminata stem extract can increase the activity of Super Oxide Dismutase (SOD) and catalase. ${ }^{10}$ Terpenoids saponin has the effect of increasing the activity and amount of macrophages, thus Musa acuminata stem extract is a potential immunostimulator. ${ }^{11}$

Condensed tannins is the polymers of flavonoid compounds with carbon-carbon bond, which will increase the insulin receptor signaling. In a previous research showed that the insulin receptor can cause auto phosphorylation at TKD (Tyrosine Kinase Domain). The receptor of tyrosine kinase is a regulation key of cellular processes such as in proliferation and differentiation, survival and metabolism, migration, and cycle control. ${ }^{12-14}$

Musa acuminata stem extract also contains terpenoids saponin, such as bioactive compounds on the stem Musa paradisiaca (Ambon banana). ${ }^{15}$ Terpenoids saponin increases the activity and amount of macrophages, which also occurs in Centella asiatica (gotu kola plant). ${ }^{16}$

Previous research showed that plants contain antioxidants are potential immunomodulator. Immunomodulatory plants have the immunostimulator and immunosuppressants effects in accordance with the conditions that affected by the extract concentration. ${ }^{17}$ Musa acuminata stem extract has antioxidant and immunostimulator nature that capable increasing the amount of macrophages and neovascular, so Musa acuminata stem extract classified as immunomodulatory plant. Musa acuminato stem extract capable to increase the amount of neovascular by angiogenesis process which is an instrumental part in the process of wound healing. This requires nutritional support to the cell metabolism, such as tannins and saponins. Approximately $60 \%$ of the granulation tissue consisting of blood vessels that need oxygen to blood vessels repairment and growth. ${ }^{18}$

The research results showed that the $25 \%$ of Musa acuminata stem extract gel application had no significant difference with Aloe vera extract gel application. This was because both the Aloe 
vera extract gel and Musa acuminata stem extract gel contains the same compounds, which were tannins, saponins, and flavonoids, so these two substances had similar effects of accelerating wound healing time.

Previous research proved that the bioactive ingredients of Musa acuminata stem contains $67.59 \%$ tannins, $14.49 \%$ saponins, $0.34 \%$ alkaloids, $0.44 \%$ ascorbic acid, $0.25 \%$ flavonoids, and $0.006 \%$ lycopene. The main bioactive ingredients are tannins and saponins. Condensed tannins has the antioxidant effects that capable to reduce the Reactive Oxygen Species (ROS), as proved by previous research that Musa acuminata stem extract was capable to increase the activity of Super Oxide Dismutase (SOD) and catalase. ${ }^{10}$ Terpenoids saponin has the effect of increasing the activity and amount of macrophages, thus Musa acuminata stem extract is a potential immunostimulator. ${ }^{11}$

\section{CONCLUSION}

At the concentration of $25 \%$ Musa acuminata stem extract gel concentration has the same healing time with Aloe vera gel, therefore can be recommended as a topical use for traumatic ulcer healing.

\section{REFERENCES}

1. Laskaris G. Treatment of oral diseases: A concise textbook. New York: Thieme; 2005. p. 169.

2. Regezi JA, Sciuba JJ, Jordan RCK. Oral pathology: Clinical pathologic correlations. $4^{\text {th }}$ ed. Philadelphia: W.B. Saunders. 2003. p. 23-6.

3. Greenberg MS, Glick M, Ship JA. Burket's oral medicine. $11^{\text {th }}$ ed. Hamilton: B.C. Decker; 2008. p. 194-201.

4. Apriasari ML. The management of chronic traumatic ulcer in oral cavity. Majalah Kedokteran Gigi (Dental Journal) 2012 June;45(2):68-72.

5. Ayuningtyas NF, Listiana I, Ernawati DS. Ekspresi interleukin-8 dan interleukin-10 akibat pemberian lactoferin $1 \%(10 \mathrm{mg} / \mathrm{g})$ pada traumatic ulcer. Thesis. Program Studi Ilmu Kesehatan Gigi Fakultas Kedokteran Gigi
Universitas Airlangga; 2012. p. 1-3,33-42.

6. Apriasari ML. Potensi batang pisang mauli (Musa acuminata) sebagai obat topikal pada penyembuhan luka mulut. Kalimantan: PT Grafika Wangi; 2015. p. 1-70.

7. Maulana R, Widodo, Cholil. Efektivitas ekstrak metanol getah batang pisang terhadap lama penyembuhan luka pada mukosa mencit. Jurnal Kedokteran Gigi Dentino 2013;1(1):94-100.

8. Apriasari ML, Adhani R, Savitri D. Uji sitotoksisitas ekstrak metanol batang pisang mauli (Musa sp.) terhadap sel fibroblast Baby Hamster Kidney (BHK) 21. Jurnal Kedokteran Gigi Dentino 2014;2(2):210-4.

9. Apriasari ML, Andini GT, Carabelly AN. Ekstrak metanol batang pisang mauli (Musa sp.) dosis 125-1000 mg/kg bb tidak menimbulkan efek toksis pada hati mencit (Mus musculus). Jurnal Kedokteran Gigi Dentofasial 2013;12 (2):81-5.

10. Noor WF, Apriantia N, Saputra SR, Apriasari $M L$, Suhartono E. Oxidative stress on buccal mucosa wound in rat and rule of topical application of ethanolic extracts of mauli banana (Musa acuminata) stem. J Trop Lif Scie 2015;5(2):84-7.

11. Bedir E, Pugh N, Calis I, Pasco DS, Khan IA. Immunostimulatory effects of cycloartanetype triterpene glycosides from astragalus species. Biol Pharm Bull 2000;23(7):834-37.

12. Jayanegara A, Sofyan A. Penentuan aktivitas biologis tanin beberapa hijauan secara in vitro menggunakan 'Hohenheim gas test' dengan polietilen glikol sebagai determinan. Media Peternakan 2005;31(1):44-52.

13. Lemmon MA, Schlessinger J. Cell signaling by receptor tyrosine kinases. Philadelphia: Elsevier Inc.; 2010. p. 1117-21.

14. Taher M, Majid FAA, Sarmidi MR. A proantocyanidin from cinnamomum zeylanicum stimulates phosphorylation of Insulin Receptor In 3T3-L1 Adipocytes. Jurnal Teknologi 2006;44(F):53-68.

15. Prasetyo BF, Wientarsih I, Pontjo B. Aktivitas sediaan salep ekstrak batang pohon pisang ambon (Musa paradisiaca var sapientum) dalam proses penyembuhan luka pada mencit (Mus musculus albnus). Majalah Obat Tradisional 2010;15(3):121-37.

16. Besung INK. Pegagan (Centella asiatica) sebagai alternatif pencegahan penyakit 
infeksi pada ternak. Buletin Veteriner Udayana 2009;1(2):61-7.

17. Mukherjee PK, Nema NK, Bhadra S, Mukherjee D, Braga FC, Matsabisa G. Immunomodulatory leads from medicinal plants. Indian J Trad
Knowl; 2014;13(2):235-56.

18. Majewska I, Darmach EG. Proangiogenic activity of plant extracts in accelerating wound healing: a new face of old phytomedicines. Acta Biochimica Polonica 2011;58(4):449-60. 